\title{
GENERAL DESIGN SISTEM INFORMASI PENGGAJIAN BERBASIS POINT SYSTEM DENGAN METODE WATER FALL
}

\author{
Muhammad Taufiq ${ }^{1)}$, Sarmidi'), Cecep Riki³), Nandhini Hudha Anggarasari ${ }^{4)}$, Iva Afifah ${ }^{\text {5) }}$, Utari Nur \\ Ambiya', Dzaky Muhammad Nur Waffi ${ }^{7)}$, Rifqi Aminullah ${ }^{8)}$ \\ 1,3,5,6,7,8) Pendidikan Teknologi Informasi, FKIP, Universitas Muhammadiyah Tasikmalaya, ${ }^{2)}$ Komputerisasi \\ AkuntansiSTIMIK Tasikmalaya, ${ }^{4)}$ Pendidikan Guru Pendidikan Anak Usia Dini, FKIP, Universitas \\ Muhammadiyah Tasikmalaya \\ Email: ${ }^{1}$ mtaufig@umtas.ac.id, ${ }^{2}$ sarmidi@stmik-tasikmalaya.ac.id,${ }^{3)}$ cecep.riki@umtas.ac.id, \\ 4)nandhini.hagrs@umtas.ac.id, ${ }^{5)}$ ivafifah2014@ gmail.com, ${ }^{6)}$ utarinur08@gmail.com , ${ }^{7)}$ waffidzaki@gmail.com, \\ 8) rifqia@gmail.com
}

\begin{abstract}
ABSTRAK
Berawal dari permasalahan yang sering muncul didalam sebuah perusahaan atau instansi tentang sistem penggajian, baik itu berupa kesalahan dalam pengelolaan gaji menyangkut cara perhitungan atau pola penentuan besaran gaji setiap karyawan, sehingga menimbulkan suasana kerja yang kurang kondusif dan kurang harmonis antar karyawan didalam lingkungan manajemen, akibatnya terjadi penurunan motivasi (demotivation) kerja karyawan, dengan ditandai banyaknya keluhan, kelesuan, dan kecurigaan para karyawan, baik dalam hubungan fungsional maupun struktural. Kondisi semacam ini akan berdampak langsung terhadap semangat kerjan yang dapat berakibat fatal pada kelangsungan perusahaan. Untuk itu, diperlukan adanya suatu solusi yang memadai, tentang sistem penggajian yang transparan dan akuntable. Transparan dalam arti terbuka lebar denga jelas terhadap cara penentuan atau perhitungan gaji setiap karyawan berdasarkan formulasi yang terstandarisasi, dimana semuanya akan dilakukan secara computerize berdasarkan point system yang berlaku. Adapun akuntable berarti dapat dipertanggungjawabkan terhadap hasil yang diperoleh dalam sistem informasi penggajian berbasis Teknologi Informasi.
\end{abstract}

Kata Kunci: Penggajian, point system, Transparan, Akuntabel, Sistem Informasi

\section{PENDAHULUAN \\ 1.1. Latar Belakang}

Permasalahan dalam sistem penggajian karyawan pada sebuah perusahaan bukan sebuah permasalahan yang sepele, bisa jadi dirasakan simple, namun sangat pelik untuk dipecahkan, karena menyangkut hajat orang banyak didalam perusahaan yang terkait terhadap pemenuhan kebutuhan hidup karyawan serta kelangsungan hidup perusahaan diamasa yang akan dating. Menurut Pasal 1 ayat 30 UU No. 13 Tahun 2003 tentang Ketenagakerjaan (UNDANGUNDANG REPUBLIK INDONESIA NOMOR 13 TAHUN 2003, 2003), Upah adalah hak pekerja/buruh yang diterima dan dinyatakan dalam bentuk uang sebagai imbalan dari pengusaha atau pemberi kerja kepada pekerja/buruh yang ditetapkan dan dibayarkan menurut suatu perjanjian kerja, kesepakatan, atau peraturan perundang - undangan, termasuk tunjangan bagi pekerja/buruh dan keluarganya atas suatu pekerjaan dan/atau jasa yang telah atau akan dilakukan

Namun, dalam menetapkan besarnya upah, pengusaha dilarang membayar lebih rendah dari ketentuan upah minimum yang telah ditetapkan pemerintah setempat (Pasal 90 ayat 1 UU No. 13/ 2003). Apabila pengusaha memperjanjikan pembayaran upah yang lebih rendah dari upah minimum, maka kesepakatan tersebut batal demi hukum (Pasal 91 ayat 2 UU No. 13/2003). Setiap pekerja/buruh berhak memperoleh penghasilan yang memenuhi penghidupan yang layak bagi kemanusiaan (Pasal 88 ayat 1 No. 13/2003).

Kebijakan pemerintah mengenai pengupahan yang melindungi pekerja/buruh meliputi:

a. Upah minimum

b. OUpah kerja lembur

c. Upah tidak masuk kerja karena berhalangan

d. Upah tidak masuk kerja karena melakukan kegiatan lain di luar pekerjaannya

e. Upah karena menjalankan hak waktu istirahat kerjanya

f. Bentuk dan cara pembayaran upah

g. Denda dan potongan upah

h. Hal-hal yang dapat diperhitungkan dengan upah

i. Struktur dan skala pengupahan yang proporsional

j. Upah untuk pembayaran pesangon; dan

k. Upah untuk perhitungan pajak penghasilan.

Komponen upah sendiri terdiri dari upah pokok dan tunjangan tetap, maka besarnya upah pokok sedikitdikitnya $75 \%$ dari jumlah upah pokok dan tunjangan tetap (Pasal 94 UU No. 13/2003)

Gaji (Ranupandojo \& Husnan, 1994) merupakan hak terpenting bagi karyawan, dimana pemenuhannya harus diperhatikan dengan baik dan benar, sehingga tentunya diatur, ditetapkan dan dibayar sesuai dengan perjanjian kerja, kesepakatan, dan juga peraturan dalam undangundang. Untuk itu dalam riset kali ini akan dibahas lebih lanjut tentang cara 
menentukan gaji karyawan bedasarkan kompetensi, dan setiap perusahan memiliki kebijakan, metoda dan formula tersendiri dalam menentukan gaji bagi karyawannya

Untuk itu perlu adanya sebuah kajian model dari sistem penggajian yang dapat memberikan kontribusi yang memadai, transparansi, dan dapat dipertanggungjawabkan, sehingga diharapkan dapat memberikan pengaruh terhadap kinerja karyawan yang dapat meningkatkan produktifitas perusahaan untuk tetap eksis didalam menghadapi segala kompetisi, karena karyawan atau sumber daya manusia dalam perusahaan merupakan asset termahal

\subsection{Tinjuan Pustaka}

Sumber Daya Manusia (SDM) atau sering disebut karyawan dalam sebuah perusahaan merupakan salah satu asset (kekayaan) yang dimiliki sebagai penentu kesuksesan dari sebuah perusahaan atau institusi, meskipun demikian tidak menutup kemungkinan jika dibalik itu semua dapat memberikan konsekuensi yang menyebabkan suatu badan usaha harus terpaksa "tutup", karena bisa jadi perlakuan terhadap SDM tersebut tidak mengangkat kaidah dan norma kemanusiaan, sehingga mengakibatkan banyaknya SDM yang mengalami demotivation, unloyality, unproductivity, dan hilangnya self confidence, sehingga berujung pada kerugian pada perusahaan

Disisi lain tumbuh kembang perusahaan akan mengakibatkan pertambahan dari jumlah SDM dalam perusahaan yang dilakukan melalui proses recruitment, hal diakibatkan dari tuntutan kebutuhan bidang pekerjaan yang ada, sehingga mau tidak mau sebuah perusahaan harus (wajib) berfikir keras untuk memenuhi kebutuhan dasar dari setiap SDM berupa haq penuh yang diterima sebagai konsekuensi dari kewajiban yang telah dilakukan, dimana haq penuh yang harus diterima SDM dalam jangka waktu yang telah ditentukan, itulah yang disebut dengan Gaji

Pengelolaan terhadap gaji yang harus diterimakan pada setiap SDM disebut dengan penggajian, dan hal ini semestinya dikelola dengan baik dan benar, agar dapat memberikan kontribusi yang mampu mengangkat nilai - nilai kemanusiaan, berupa Keadilan dan Kesejahteraan bagi para pekerja atau karyawan, baik dalm tinjauan struktural maupun secara fungsional, karena menyangkut beban kerja dan risiko pekerjaan yang dijalani. Untuk itulah, perlu dibagun sebuah sistem penggajian yang memadai atau selaras dengan budaya (kultur) serta manajemen perusahaan

Prinsip dasar (Toban \& Sjahruddin, 2016) dalam sistem penggajian pada sebuah perusahaan secara umum dapat diuraikan sebagai berikut: a. Penetapan Deadline (Batas Waktu) Penggajian. Sistem penggajian perlu memperhatikan batas waktu penggajian yang berlaku untuk karyawannya berlandaskan pada jangka (tempo) yang telah disepakati bersama, baik dalam harian, mingguan, atau bulanan, maka SDM yang ada tidak berlalu lagi bertanya tanya tentang waktu penggajiannya, kapan akan diterimakan. Penetapan waktu penggajian juga sangat membantu dalam proses manajemen perusahaan secara keseluruhan, karena jumlah keuangan terbesar yang harus (wajib) dikeluarkan dan tidak dapat dihindari dalam perusahaan terletak pada penggajian, besarnya hampir sekitar $40-50 \%$ dari penghasilan perusahaan. Oleh karena itu, dibutuhkan perencanaan yang matang dalam pengelolaan penggajian.

b. Perhitungan Besaran Gaji, Penentuan besaran gaji bagi setiap karyawan cukup kompleks dan bukan sebuah persoalan yang sepele untuk dikerjakan, namun banyak faktor yang mempengaruhi dalam mengformulasikan besaran gaji tersebut, artinya diberi gaji dalam jumlah besar atau jumlah kecil belum tentu akan menentukan dalam penyelesaian masalah yang terjadi. Besar kecilnya gaji yang diterimakan pada setiap karyawan sangat relatif, karena setiap karyawan memliki kebutuhan yang berbeda berdasarkan kepentingan. Oleh karena itu, dalam penentuan besaran gaji karyawan bukan didasarkan pada tingkat kebutuhan setiap karyawan, namun lebih ditekankan pada potensi dan prestasi kerja karyawannya, sehingga perlu adanya sebuah sistem penggajian yang telah diformulasikan sedemikian rupa untuk menjawab persoalan dan permasalahan dalam kehidupan kerja perusahaan yang tidak lepas kaitannya dengan keberadaan SDM itu sendiri

c. Pembangunan Automatisasi Sistem Penggajian. Untuk menunjang pelaksanaan sistem penggajian yang memadai atas kebutuhan perusahaan, maka tidak lepas dari pembangunan sistem penggajian yang berkualitas untuk mampu menjawab tantangan dalam pengelolaan karyawan secara keseluruhan, baik terhadap level puncak hingga level dasar maupun terhadap seluruh pekerja yang terlibat. Oleh karena itu, dukungan teknologi informasi terhadap penggunaan teknologi komputer dalam sistem penggajian sangat dibutuhkan, sehingga tercipta sebuah aplikasi berupa software sebagai media proses automatisasi penggajian. Dengan adanya pembangunan sistem Penggajian yang berbasis teknologi informasi ini, maka diharapkan dapat memberikan kontribusi yang utuh dan futuh (terbuka) terhadap manajemen perusahaan. Jadi harapan untuk transparansi dan 
akuntanbilitas terhadap sistem penggajian dapat terwujud sebagaimana mestinya, termasuk aspek pelayanan didalam mendistribusikan gaji pada setiap karyawan serta pelaporan pajak yang berlaku

d. Perencanaan Finansial untuk Penggajian. Gaji merupakan persoalan tersendiri dan khusus bagi manajemen keuangan sementara kinerja dan pengembangan SDM terletak manajemen SDM, dimana kedua manajemen ini saling beririsan (intersection), sehingga dibutuhkan sebuah perencanaan finansial yang terkait terhadap kinerja dan pengembangan SDM secara menyeluruh, sebab aspek terbesar dalam penentuan pemasukan atau pendapatan perusahaan ada pada kinerja karyawan, dan hal itu tidak lepas dari pengembangan potensi bagi karyawan yang ada. Oleh sebab itu, perencanaan finansial untuk penggajian karyawan perlu diperhitungkan secermat mungkin, agar segala kendala dalam penggajian dapat diatasi, sehingga keterlambatan atau hutang gaji karyawan dapat dihindari lebih dini

e. Penentuan Metoda Penggajian. Metoda dalam sistem penggajian karyawan banyak jenis dan variasinya, menyangkut berbagai aspek pertimbangan yang berlaku dalam perusahaan, seperti karyawan yang sudah terlibat sejak berdirinya perusahaan, karyawan yang baru masuk menjadi seorang tenaga kerja, karyawan yang sudah masuk saat perusahaan berjalan (atau memiliki masa kerja), dan lainnya. Disamping itu karyawan yang menduduki pada sebuah level manajemen tertentu, pastinya memiliki risiko dan tanggunjawab yang berbeda pada setiap levelnya, demikian juga karyawan yang bekerja dibawah tekanan akan memiliki risiko lebih tinggi dibanding karyawan yang ada dalam kerja administrasi, dan lainnya. Oleh karena itu, perlu adanya sebuah metoda yang digunakan untuk menentukan sistem penggajian agar aspek keadilan dan kesejahteraan dapat dijalankan sebagaimana mestinya. Salah satunya adalah sistem pengggajian dengan metoda point system, yakni setiap karyawan akan ditentukan berapa besarnya point yang harus diterima berdasarkan kriteria dan klasifikasi yang telah ditentukan secara bersama - sama, dan dari point yang diterima pada karyawan akan dikalikan dengan besaran koin (nilai rupiah per poin) yang berlaku, dan hasilnya sebagai penentu besaran (total) gaji yang harus diterima setiap perioda waktu yang berlangsung

Tahapan Penentuan gaji (Ranupandojo \& Husnan, 1994) merupakan rangkaian kegiatan untuk menetapkan besaran gaji yang sesuai dengan ukuran (takaran) terhadap pekerjaan atau sejumlah pekerjaan yang telah dilakukan seorang karyawan berdasarkan perjanjian, kesepakatan, maupun peraturan perundang - undangan yang ada, sehingga kedua belah fihak antara karyawan (pekerja) dengan pemberi kerja (pengusaha) tidak ada yang merasa dirugikan, atau dengan kata lain "win - win solution".

Adapun tahapan penentuan gaji terdiri atas:

a. Analisis Jabatan merupakan serangkaian aktivitas untuk menguraikan pekerjaan pekerjaan yang dilakukan serta persyaratan yang diperlukan sehingga dapat merumuskan uraian pekerjaan (job description), spesifikasi pekerjaan (job spesification), dan standar kinerja (performance standart), aktivitas analisis ini dilakukan sebagai landasan dalam mengevaluasi jabatan berupa jenjang jabatan dan jenjang kepangkatan

a) Jenjang jabatan, Setiap organisasi (perusahaan) meliputi sejumlah kelompok pekerjaan yang pastinya mempunyai syarat jabatan dengan spesifikasi tersendiri, dan syarat jabatan tersebut mencerminkan sifat dan kompleksitas pekerjaan dan kelompok pekerjaan dalam unit organisasi yang dalam pelaksanaannya memerlukan syarat-syarat tertentu

b). Jenjang Kepangkatan, Kualifikasi atas kemampuan seorang karyawan dalam menjalankan pekerjaan dipengaruhi beberapa faktor, diantaranya tingkat pendidikan, akumulasi pelatihan, dan pengalaman kerja. Dan dari sinilah dapat ditentukan jenjang kepangkatan yg digunakan untuk menggambarkan kualifikasi seorang karyawan untuk menenmpati posisi jabatan yang sesuai, disusun berdasarkan kompleksitas jabatan dan tanggung jawab yang dipikul

b. Evaluasi Jabatan (Pekerjaan) merupakan proses sistematis untuk mengukur nilai relatif dari suatu pekerjaan terhadap pekerjaan lain, dalam mengupayakan penetuan tingkat Gaji melalui pencapaian internal equity dalam pekerjaan, adapun faktor-faktor yang dipertimbangkan dalam melakukan evaluasi pekerjaan, terdiri atas tanggung jawab, keterampilan atau kemampuan, tingkat usaha yang dilakukan dalam pekerjaan dan lingkungan kerja, sedangkan metode dalam evaluais pekerjaan:

a). Job Ranking Method, mengukur tingkat kepentingan pekerjaaan secara umum dari suatu pekerjaan berdasarkan analisis jabatan, melaluli job description, job specification dan job performance standard, lalu secara subjektif berdasarkan tingkat kepentingan diakukan pengurutan pekerjaan 
b). Job Grading Method, mengukur klasifikasi (pengklasifikasian) atau tingkat kategori suatu pekerjaan, yaitu kelompok kelas jika berisi jabatan yang sama dan kelompok tingkatan jika berisi pekerjaan berbeda namun mempunyai tingkat kesulitan yang sama

c). Job Comparison Method, mengukur perbandingan beberapa faktor pekerjaan kunci terhadap beberapa faktor yang dapat digaji, seperti tanggung jawab, skill (ketrampilan), tingkat usaha dan kondisi kerja

d). Job Determining Method, mengukur dengan cara menentukan besaran poin (angka) untuk faktor-faktor yang dapat digaji, dan masing - masing faktor yang dapat digaji diuraikan kedalam subfaktor yang lebih rinci, kemudian ditentukan level dari point masingmasing faktor, misal tanggung jawab terbagi atas tanggung jawab atas: peralatan dan bahan, perbaikan, keamanan, dan kendaraan. Ketrampilan terbagi atas pengalaman dan pendidikkan, tingkat usaha terbagi atas usaha mental dan usaha fisik, jika perlu lingkungan kerja yang menyertai karyawan juga dapat diuraikan

c. Survei Gaji atas Jabatan merupakan langkah langkah untuk mengetahui dan memahami seberapa besar tingkat gaji yang diberlakukan secara umum dari setiap jabatan yang sama pada perusahaan-perusahaan sejenis. Upaya ini dilakukan untuk mendapatkan kesetaraan sosial antar perusahaan, dan dapat dilakukan dengan melalui methodolgi riset seperti kuesioner, observasi langsung, atau lainnya yang dianggap relevan dan etis

d. Tingkat Gaji atas Jabatan merupakan tahapan akhir dalam menentukan tingkat gaji yang memadai (adil) dan sesuai (layak) secara komprehensif, yang dilakukan setelah evaluasi jabatan dan survey gaji

Peranan gaji dalam sebuah perusahaan sangat bergantung pada kedua belah fihak yang ada dalam operasional perusahaan, oleh karenanya menurut (Poerwono, n.d.) peranan gaji dibagi atas 2 aspek tinjauan, yaitu:

a. Tinjauan dari fihak pemberi kerja (majikan), yakni para eksekutif atau manager, Gaji merupakan unsur pokok dalam menghitung biaya produksi dan komponen dalam menentukan harga pokok sebagai penentu kelangsungan hidup perusahaan. Apabila perusahaan memberikan gaji terlampau tinggi, maka akan berdampak pada kenaikan harga pokok dan jika gaji yang diberikan terlampau rendah akan berdampak kesulitan dalam mendapatkan tenaga kerja yang dibutuhkan b. Tinjauan dari fihak penerima kerja yakni para pekerja, Gaji merupakan penghasilan atau pendapatan yang diterima oleh seorang karyawan perusahaan yang akan digunakan sebagai pemenuhan kebutuhan, dimana Gaji merupakan salah satu motivasi penting yang ikut mendorong karyawan dalam berprestasi, sehingga bisa jadi gaji yang diberikan akan mempengaruhi kinerja karyawan dan kesetiaan (loyalitas) karyawan terhadap perusahaan

Fungsi gaji tidak hanya sekedar membantu manajer personalia (bagian dari manajemen SDM) dalam menentukan gaji yang adil dan layak, namun tidak lepas dari fungsi-fungsi manajemen lain, dan menurut (Hasibuan, 2002) diantaranya:

a. Gaji berfungsi untuk menarik karyawan (pekerja) yang mempunyai kemampuan ke dalam organisasi perusahaan

b. Gaji berfungsi untuk mendorong karyawan agar menunjukkan prestasi yang lebih baik dan produktif

c. Gaji berfungsi untuk memelihara prestasi karyawan selama periode yang panjang demi kelangsungan usaha

Tujuan penggajian pada prinsipnya mampu menyelaraskan jalannya perusahaan secara optimal dan maksimal sejalan dengan pemenuhan kebutuhan para karyawaan perusahaan sehingga tujuan perusahaan itu sendiri dapat tercapai dengan baik (efisien dan efektif), dan menurut (Hasibuan, 2002) tujuan penggajian dapat disampaikan sebagai berikut:

a. Ikatan kerja sama, dengan pemberian gaji terjalin kesebandingan hubungan kerja antara majikan dengan karyawan, korelasinya karyawan akan mengerjakan tugas dengan baik sehingga konskuensinya pengusaha atau majikan wajib akan memberikan kontribusi gaji yang disepakati.

b. Kepuasan kerja, dengan kontribusi gaji yang diberikan pada karyawan maka akan dapat memenuhi kebutuhan - kebutuhan dasar sehingga memperoleh kepuasan kerja dari jabatan yang diemban

c. Rekruitmen karyawan yang efektif, program kontribusi gaji berkorelasi sebanding terhadap rekruitmen / pengadaan karyawan yang memenuhi kualifikasi

d. Motivasi kerja, program kontribusi gaji juga berkorelasi sebanding terhadap kinerja karyawan

e. Stabilitas karyawan, dengan kontribusi gaji yang berprinsip adil, layak dan secara eksternal memiliki konsistensi yang kompetitif maka turnover relatif kecil sehingga stabilitas karyawan lebih terjamin

f. Disiplin kerja karyawan, program kontribusi gaji berkorelasi sebanding terhadap disiplin kerja karyawan, akibatnya karyawan akan 
menyadari serta mentaati peraturan - peraturan yang diberlakukan

g. Dampak Serikat Buruh, dengan program kontribusi gaji yang baik maka dampak serikat buruh bisa dihindari akibatnya karyawan akan konsentrasi atas pekerjaan

h. Dampak kebijakan Pemerintah, kontribusi gaji yang sesuai dengan undang - undang yang berlaku (seperti batas gaji minimum) maka intervensi kebijakan pemerintah dapat dihindari

\subsection{Metodologi Penelitian}

Sistem penggajian dengan point system merupakan penggajian berdasarkan kompetensi yang digunakan untuk mengembangkan keterampilan yang lebih luas dan lebih dalam bagi para karyawan. Kompetensi tinggi yang dimiliki oleh setiap karyawan dalam perusahaan akan menentukan kualitas kompetitif dari perusahaan itu sendiri. Sistem penggajian bedasarkan point system ini dinilai lebih baik karena keahlian, dan pengetahuan yang terukur adalah hal penting dari proses manajemen kinerja karyawan perusahaan. Keberhasilan sistem penggajian berdasarkan point system dilihat pada aspek penilaian karyawan yang meningkat terkait dengan keahlian baru, peningkatan keahlian akan memberikan dampak langsung terhadap penggajian yang lebih baik.

Tujuan dari penelitian (Moenir \& Yuliyanto, 2017) ini diharapkan dapat membangun atau mengembangkan sebuah model sistem informasi penggajian berbasis teknologi informasi (IT) yang dikelola dengan menggunakan komputer dalam rangka untuk menjawab permasalahan yang ada pada sistem penggajian berdasarkan point system. Dengan dibangunnya sistem informasi penggajian berbasis IT, akan membantu dalam pemecahan masalah dan pengambilan keputusan manajemen, sehingga sistem penggajian ini bersifat transparansi, akuntabilitas, dan profesionalisme, artinya sistem penggajian ini terbuka terhadap semua tindakan dan kebijakan yang diambil manajemen, sistem penggajian ini memenuhi konsep etika yang dekat dengan administrasi manajemen perusahaan, dan sistem penggajian ini memiliki sifat-sifat berupa kemampuan, kemahiran, cara pelaksanaan sesuatu dan lain-lain yang sewajarnya serta bertanggung jawab

Metode analisis point system dinilai lebih akurat, lebih transparan, dan lebih akuntable, adapun untuk menentukan nilai suatu jabatan dalam point system dapat dilakukan sebagai berikut:

a. Memilih dan menentukan nilai terhadap faktor - faktor jabatan, yakni sebuah kebutuhan khusus terhadap pemangku jabatan yang diperlukan untuk dapat memberikan kontribusi dalam penyelesaian pekerjaan, dimana faktor jabatan ini akan digunakan sebagai standart dalam penetapan upah atau gaji karyawan. Faktor - faktor jabatan ini umumnya dibagi dalam 4 (empat) kriteria dengan 11 (sebelas) sub faktor, yaitu:

a). Faktor Ketrampilan, meliputi sub faktor: Pendidikan, Pengalaman, Inisiatif

b). Faktor Usaha, meliputi sub faktor: Usaha Fisik, Usaha Mental

c). Faktor Tanggung Jawab, meliputi sub faktor: Tanggung jawab peralatan / proses, Tanggung jawab bahan / produk, Tanggung jawab keamanan oranglain, Tanggung jawab pekerjaan orang lain

d). Faktor Kondisi, meliputi sub faktor: Kondisi kerja, Resiko kerja

b. Menetapkan derajat (tingkatan) atas faktor faktor jabatan berikut kriterianya, berupa standart pengukur terhadap setiap jabatan jabatan yang akan dinilai

c. Menetapkan nilai point dalam menilai sebuah jabatan, yaitu nilai point yang ditentukan terhadap setiap sub faktor jabatan yang telah dibangun dalam Tabel 1., dan untuk menetapkan point - point ini dapat ditentukan secara bebas dengan mempertimbangkan derajat dan definisi-nya pada setiap sub faktor yang ada

Setelah point pada setiap derajat ditentukan, maka penetapan nilai terhadap masing - masing jabatan sudah dapat dilakukan, dimana spesifikasi jabatan untuk setiap jabatan yang dinilai dapat dibaca dari kriteria yang ada, sehingga total point pada setiap jabatan dapat diketahui besarannya.

Total point yang diketahui atau yang didapatkan akan digunakan sebagai patokan dalam menerjemahkan point kedalam term moneter, yaitu besaran rupiah yang ditetapkan untuk setiap pointnya.

Nilai rupiah untuk setiap point dapat ditentukan dengan melakukan survey gaji / upah atau dengan menggunakan anggaran yang tersedia, dengan demikian struktur penggajian pada setiap jabatan akan dapat ditentukan besaran nilai gaji yang harus diterima

Analisis pengembangan dan perancangan (MUNIARTO, 2017) dalam melakukan pemodelan Sistem Informasi Penggajian berdasarkan point system dilakukan dengan menggunakan metode water fall (air terjun), dimana metode water fall ini dapat digambarkan sebagai berikut: 


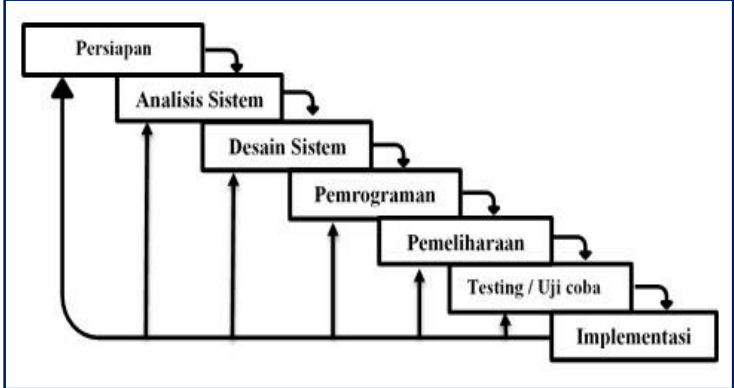

Gambar 1. Metode Water Fall

Metode waterfall sering disebut dengan siklus hidup perangkat lunak, yakni mengambil kegiatan dasar seperti spesifikasi, pengembangan, validasi, evolusi dan merepresentasikan sebagai fase-fase proses yang berbeda seperti spesifikasi persyaratan, perancangan perangkat lunak, implementasi, pengujian dan seterusnya.

Pertimbangan dengan menggunakan metode water fall (SASTRA RICKY, 2019) ini adalah setiap langkah dalam melakukan tindakan untuk pengembangan sistem dilakukan evaluasi terlebih dahulu terhadap kebutuhan - kebutuhan yang ada sebelum melakukan tindakan pengembangan berikutnya, sehingga dengan menggunakan metode ini diharapkan menghasilkan sistem yang lebih akurat dan lebih proporsioanl, hanya kelemahan dengan menggunakan metode ini membutuhkan waktu yang cukup lama

Keuntungan dalam menggunakan metode waterfall adalah proses lebih terstruktur, hal ini membuat kualitas software baik dan tetap terjaga., sedangkan pada sisi user juga lebih menguntungkan, karena dapat merencanakan dan menyiapkan kebutuhan data dan proses yang diperlukan sejak awal. Penjadwalan juga menjadi lebih menentu, karena jadwal setiap proses dapat ditentukan secara pasti.

\section{PEMBAHASAN}

Untuk menetapkan besaran gaji yang diterima dari sebuah jabatan berdasarkan point system, maka terlebih dahulu dilakukan Penetapan derajat (tingkatan) pada setiap faktor jabatan dari kriteria yang ada, sebagaimana ditunjukkan dalam tabel berikut ini:

Tabel 1. Penetapan derajat terhadap faktor faktor jabatan

\begin{tabular}{|c|c|c|c|}
\hline $\begin{array}{c}\text { Faktor Jabatan } \\
\text { dan }\end{array}$ & \multicolumn{3}{|c|}{ erajat dan Kriteria } \\
\hline & 1 & 2 & 3 \\
\hline $\begin{array}{l}\text { Ketrampilan } \\
\text { - Pendidikan } \\
\text { - Pengalaman } \\
\text { - Inisiatif }\end{array}$ & $\begin{array}{l}\text { Rendah } \\
0-2 \\
\text { (tahun) } \\
\text { Rutin }\end{array}$ & $\begin{array}{l}\text { Menengah } \\
3-5 \\
\text { (tahun) } \\
\text { Bersama }\end{array}$ & $\begin{array}{l}\text { Tinggi } 5 \\
\text { tahun } \\
\text { keatas } \\
\text { Sendiri }\end{array}$ \\
\hline
\end{tabular}

\begin{tabular}{|c|c|c|c|}
\hline $\begin{array}{l}\text { Usaha } \\
\text { - Fisik } \\
\text { - Mental }\end{array}$ & $\begin{array}{l}\text { Ringan } \\
\text { Ringan }\end{array}$ & $\begin{array}{l}\text { Sedang } \\
\text { Sedang }\end{array}$ & $\begin{array}{l}\text { Berat } \\
\text { Berat }\end{array}$ \\
\hline $\begin{array}{l}\text { Tanggung Jawab } \\
\text { - Peralatan / } \\
\text { Proses } \\
\text { - Bahan / Produk } \\
\text { - Keamanan } \\
\text { Orang lain } \\
\text { - Pekerjaan } \\
\text { Orang lain }\end{array}$ & $\begin{array}{l}\text { Kecil } \\
\text { Kecil } \\
\text { Kecil } \\
\text { Kecil }\end{array}$ & $\begin{array}{l}\text { Sedang } \\
\text { Sedang } \\
\text { Sedang } \\
\text { Sedang }\end{array}$ & $\begin{array}{l}\text { Besar } \\
\text { Besar } \\
\text { Besar } \\
\text { Besar }\end{array}$ \\
\hline $\begin{array}{l}\text { Kondisi } \\
\text { - Kondisi Kerja } \\
\text { - Resiko Kerja }\end{array}$ & $\begin{array}{l}\text { Menyena } \\
\text { ngkan }\end{array}$ & $\begin{array}{l}\text { Cukup } \\
\text { Sedang }\end{array}$ & $\begin{array}{l}\text { Tidak } \\
\text { menyenan } \\
\text { gkan } \\
\text { Besar }\end{array}$ \\
\hline
\end{tabular}

Selanjutnya setelah penetapan derajat dilakuka penetapan nilai poin terhadap faktor - faktor jabatan sebagaimana ditunjukan dalam tabel berikut:

Tabel 2. Penetapan poin terhadap faktor faktor jabatan

\begin{tabular}{|c|c|c|c|c|}
\hline Faktor Jabatan dan Sub & \multicolumn{4}{|c|}{ Derajat dan Kriteria } \\
\hline & 1 & 2 & 3 & $\begin{array}{l}\text { Total } \\
\text { Poin }\end{array}$ \\
\hline $\begin{array}{l}\text { Ketrampilan } \\
\text { - Pendidikan } \\
\text { - Pengalaman } \\
\text { - Inisiatif }\end{array}$ & $\begin{array}{l}10 \\
15 \\
10\end{array}$ & $\begin{array}{l}20 \\
30 \\
20\end{array}$ & $\begin{array}{l}30 \\
45 \\
30\end{array}$ & 105 \\
\hline $\begin{array}{l}\text { Usaha } \\
\text { - Fisik } \\
\text { - } \text { Mental }\end{array}$ & $\begin{array}{c}10 \\
5\end{array}$ & $\begin{array}{l}20 \\
10\end{array}$ & $\begin{array}{l}30 \\
15 \\
\end{array}$ & 45 \\
\hline $\begin{array}{l}\text { Tanggung Jawab } \\
\text { - Peralatan / Proses } \\
\text { - Bahan / Produk } \\
\text { - Keamanan Orang lain } \\
\text { - Pekerjaan Orang lain }\end{array}$ & $\begin{array}{l}5 \\
5 \\
5 \\
\\
5\end{array}$ & $\begin{array}{l}10 \\
10 \\
10 \\
\\
10\end{array}$ & $\begin{array}{l}15 \\
15 \\
15 \\
\\
15\end{array}$ & 60 \\
\hline $\begin{array}{l}\text { Kondisi } \\
\text { • Kondisi Kerja } \\
\text { • Resiko Kerja }\end{array}$ & $\begin{array}{c}10 \\
5\end{array}$ & $\begin{array}{l}20 \\
10\end{array}$ & $\begin{array}{l}30 \\
15\end{array}$ & 45 \\
\hline
\end{tabular}

Sebagai contoh, untuk penetapan point system pada sebuah jabatan kepala Teknologi Informasi dan Komunikasi (TIK) dengan kriteia yang ada, dapat dilihat pada table berikut ini:

\section{Tabel 3. Contoh penetapan poin terhadap sebuah jabatan}

Jabatan: Kepala TIK

\begin{tabular}{|l|c|c|c|c|}
\hline \multicolumn{1}{|c|}{$\begin{array}{c}\text { Faktor Jabatan } \\
\text { dan } \\
\text { Sub Faktor }\end{array}$} & \multicolumn{4}{|c|}{ Derajat dan Kriteria } \\
\hline & Kriteria & $\begin{array}{c}\text { Dera } \\
\text { jat }\end{array}$ & Poin & $\begin{array}{c}\text { Nilai } \\
\text { Poin }\end{array}$ \\
\hline $\begin{array}{l}\text { Ketrampilan } \\
\text { - Pendidikan } \\
\text { - Pengalaman } \\
\text { - Inisiatif }\end{array}$ & S1 & 3 & 30 & 95 \\
\hline $\begin{array}{l}\text { Usaha } \\
\text { - Fisik } \\
\text { - Mental }\end{array}$ & & 3 & 45 & \\
\hline
\end{tabular}




\begin{tabular}{|c|c|c|c|c|}
\hline & $\begin{array}{c}\text { Sedang } \\
\text { Berat }\end{array}$ & 3 & 15 & \\
\hline $\begin{array}{l}\text { Tanggung Jawab } \\
\text { - Peralatan / } \\
\text { Proses } \\
\text { - Bahan / Produk } \\
\text { - Keamanan Orang } \\
\text { lain } \\
\text { - Pekerjaan } \\
\text { Orang lain }\end{array}$ & $\begin{array}{l}\text { Besar } \\
\text { Sedang } \\
\text { Besar } \\
\text { Besar }\end{array}$ & $\begin{array}{l}2 \\
3\end{array}$ & $\begin{array}{l}10 \\
15 \\
15\end{array}$ & 55 \\
\hline $\begin{array}{l}\text { Kondisi } \\
\text { - Kondisi Kerja } \\
\text { - Resiko Kerja }\end{array}$ & $\begin{array}{c}\text { Tidak } \\
\text { menyena } \\
\text { ngkan } \\
\text { Besar }\end{array}$ & 3 & 30 & 45 \\
\hline \multicolumn{4}{|c|}{ Total Poin } & 230 \\
\hline
\end{tabular}

Berdasarkan total poin yang diperoleh dari sebuah jabatan, maka dapat ditetapkan besaran gaji yang diterima, yaitu:

Besaran Gaji = Total Point x Nilai per poin ... (1)

Prinsip kerja dari Sistem Penggajian berdasarkan Point System ini dapat dijelaskan sebagai berikut:

a. Setiap karyawan yang telibat dalam perusahaan ditentukan nilai poin POKOKnya berdasarkan spesifikasi yang telah ditentukan, nilai poin pokok ini relatif tetap untuk setiap bulannya, jika setiap karyawan tidak melakukan pengembangan diri

b. Setiap karyawan yang telibat dalam perusahaan ditentukan nilai poin PRESTASInya berdasarkan spesifikasi yang telah ditentukan, nilai poin prestasi ini variatif untuk setiap bulannya, bergantung pada aspek penilaian prestasi yang dilakukan antar karyawan ataupun terhadap pimpinannya

c. Hasil akumulasi dari nilai poin pokok dan prestasi dijumlahkan untuk mendapatkan Total Poin dalam satu bulan

d. Total poin setiap karyawan dikalikan dengan besaran nilai uang per poin yang telah ditentukan atas dasar kebijakan manajemen

e. Nilai (uang) per poin dapat ditentukan atas dasar kebijakan manajemen atau dihitung berdasar standart baku perusahaan atau menggunakan dasar Upah Minimum Regional (UMR)

Setelah perumusan tentang point system dilakukan, maka dilanjutkan dengan Perancangan Sistem, dan sebagaimana telah diketahui bahwa perancangan sistem informasi dibagi menjadi 2 (dua) yaitu perancangan umum (general design) dan perancangan rinci (detail design)

Terkait dengan perancangan umum dari sistem informasi penggajian berbasis point system, maka dapat dibuat dengan menggunakan software My SQL, Delphy7, Gammu, dan VB. Berdasarkan hasil penelitian, ada 3 kebutuhan yang melatar belakangi permasalahan yang ada untuk dirancang sebuah sistem informasi yang memadai, yaitu:

a. Kebutuhan terhadap perhitungan gaji berdasarkan standarisasi dan prestasi kerja dari masing - masing jabatan yang telah ditetapkan

b. Kebutuhan terhadap penyajian laporan data penggajian yang terkomputerais (automatis) dan berkualitas, yakni akurat, relevan, dan tepat waktu

c. Kebutuhan terhadap penyimpanan database karyawan (biodata) dan penggajian

Untuk itu perlu dirancang sebuah basis data yang efisien dan efektif.

Normalisasi database disini dalam rangka menghilangkan aspek data rangkap (ganda), mengurangi kompleksitas, dan mempermudah dalam memodifikasi data, prosesnya meliputi:

a. First Normal Form (1 NF), ditabulasikan sebagai berikut:

Tabel 4. 1 NF - Pengguna (user)

\begin{tabular}{|l|c|c|l|}
\hline $\begin{array}{c}\text { Field } \\
\text { Name }\end{array}$ & $\begin{array}{c}\text { Data } \\
\text { Type }\end{array}$ & $\begin{array}{c}\text { Ran } \\
\text { ge }\end{array}$ & \multicolumn{1}{|c|}{ Description } \\
\hline User_name & varchar & 40 & UN pengguna \\
\hline Password & varchar & 30 & Kata kunci user \\
\hline Nama & varchar & 40 & Nama pengguna \\
\hline ID_User & int & 9 & ID pengguna \\
\hline
\end{tabular}

\begin{tabular}{|l|c|c|l|}
\multicolumn{1}{c|}{ Tabel 5. $\begin{array}{c}\text { Field } \\
\text { Name }\end{array}$} & $\begin{array}{c}\text { Data } \\
\text { Type }\end{array}$ & $\begin{array}{c}\text { Ran } \\
\text { ge }\end{array}$ & \multicolumn{1}{|c|}{ Description } \\
\hline ID_Karyawan & int & 9 & ID Karyawan \\
\hline NIK & varchar & 15 & No. Induk Karyw \\
\hline Nama & varchar & 40 & Nama Karyawan \\
\hline Alamat & text & - & Alamat karyawan \\
\hline Jenis kelamin & varchar & 1 & Jenis kelamin \\
\hline User_name & varchar & 40 & UN Karyawan \\
\hline Password & varchar & 30 & Kata kunci Karyw \\
\hline
\end{tabular}

Tabel 6. 1 NF - Jabatan

\begin{tabular}{|l|c|c|l|}
\hline $\begin{array}{c}\text { Field } \\
\text { Name }\end{array}$ & $\begin{array}{c}\text { Data } \\
\text { Type }\end{array}$ & $\begin{array}{c}\text { Ran } \\
\text { ge }\end{array}$ & \multicolumn{1}{|c|}{ Description } \\
\hline ID_Jabatan & int & 9 & Id. jabatan \\
\hline Jabatan & varchar & 30 & Nama jabatan \\
\hline
\end{tabular}

Tabel 7. 1 NF - Derajat Faktor Jabatan

\begin{tabular}{|l|c|c|l|}
\hline \multicolumn{1}{|c|}{$\begin{array}{c}\text { Field } \\
\text { Name }\end{array}$} & $\begin{array}{c}\text { Data } \\
\text { Type }\end{array}$ & $\begin{array}{c}\text { Ran } \\
\text { ge }\end{array}$ & \multicolumn{1}{|c|}{ Description } \\
\hline ID_Jabatan & int & 9 & Id. Jabatan \\
\hline Jabatan & varchar & 30 & Nama jabatan \\
\hline Pendidikan & varchar & 30 & Pendd karyawan \\
\hline Pengalaman & int & 2 & Penglm karyawan \\
\hline Inisiatif & varchar & 30 & Inisiatif karyawan \\
\hline Usaha Fisik & varchar & 30 & U. fisik karyawan \\
\hline Usaha Mental & varchar & 30 & U. mental karywn \\
\hline Peralatan & varchar & 30 & Tggjwb alat kerja \\
\hline Bahan Produk & varchar & 30 & Tggjwb bahan \\
\hline Safety_Orang & varchar & 30 & Tggjwb keamann \\
\hline Job_Orang & varchar & 30 & Tggjwb pekerjaan \\
\hline Kondisi_Job & varchar & 30 & Kondisi pekerjaan \\
\hline Risiko_Job & varchar & 30 & Risiko pekerjaan \\
\hline
\end{tabular}

Tabel 8. Total Point Faktor Jabatan

\begin{tabular}{|c|c|c|c|}
\hline $\begin{array}{c}\text { Field } \\
\text { Name }\end{array}$ & $\begin{array}{c}\text { Data } \\
\text { Type }\end{array}$ & $\begin{array}{c}\text { Ran } \\
\text { ge }\end{array}$ & Description \\
\hline
\end{tabular}




\begin{tabular}{|l|c|c|l|}
\hline Tot_Point & int & 25 & Total Point Jabatn \\
\hline \multicolumn{3}{|c|}{ Tabel 9. 1 NF - Gaji } \\
\begin{tabular}{|l|c|c|l|} 
Nameld & Data \\
Type
\end{tabular} & $\begin{array}{c}\text { Ran } \\
\text { ge }\end{array}$ & \multicolumn{1}{|c|}{ Description } \\
\hline ID_Jabatan & int & 9 & Id. Jabatan \\
\hline ID_gaji & int & 9 & Id. Gaji \\
\hline Tgl & date & - & Tanggal Gaji \\
\hline NIK & int & 2 & No. Induk Karyw \\
\hline Gj_Pokok & varchar & 30 & Gaji Pokok \\
\hline BPJS & int & 30 & Asuransi kesehatn \\
\hline TKel & int & 30 & Tunj.keluarga \\
\hline TTrans & int & 30 & Tunj.transportasi \\
\hline TStruk & int & 30 & Tunj.struktural \\
\hline TJab & int & 30 & Tunj.jabatan \\
\hline TPensiun & int & 30 & Tunj.pensiun \\
\hline
\end{tabular}

Tabel 10. 1 NF - Perusahaan

\begin{tabular}{|l|c|c|l|}
\hline $\begin{array}{c}\text { Field } \\
\text { Name }\end{array}$ & $\begin{array}{c}\text { Data } \\
\text { Type }\end{array}$ & $\begin{array}{c}\text { Ran } \\
\text { ge }\end{array}$ & \multicolumn{1}{|c|}{ Description } \\
\hline Nm_prusahaan & varchar & 40 & Id. Jabatan \\
\hline Alamat & varchar & 50 & Id. Gaji \\
\hline Logo & varchar & - & Tanggal Gaji \\
\hline Home & varchar & - & No. Induk Karyw \\
\hline Prosedur & varchar & - & Gaji Pokok \\
\hline Admin & varchar & - & Asuransi kesehatn \\
\hline
\end{tabular}

b. Second Normal Form (2 NF), ditabulasikan sebagai berikut:

Tabel 11. 2 NF - Pengguna (user)

\begin{tabular}{|l|c|c|l|}
\hline $\begin{array}{r}\text { Filed } \\
\text { Name }\end{array}$ & $\begin{array}{c}\text { Data } \\
\text { Type }\end{array}$ & $\begin{array}{c}\text { Ran } \\
\text { ge }\end{array}$ & \multicolumn{1}{|c|}{ Description } \\
\hline User_name & varchar & 40 & UN pengguna \\
\hline Password & varchar & 30 & Kata kunci user \\
\hline ID_User & int & 9 & ID pengguna \\
\hline Nama & varchar & 40 & Nama pengguna \\
\hline
\end{tabular}

Tabel 12. 2 NF - Karyawan

\begin{tabular}{|l|c|c|l|}
\hline \multicolumn{1}{|c|}{$\begin{array}{c}\text { Field } \\
\text { Name }\end{array}$} & $\begin{array}{c}\text { Data } \\
\text { Type }\end{array}$ & $\begin{array}{c}\text { Ran } \\
\text { ge }\end{array}$ & \multicolumn{1}{|c|}{ Description } \\
\hline ID_Karyawan & int & 9 & ID Karyawan \\
\hline NIK & varchar & 15 & No. Induk Karyw \\
\hline Nama & varchar & 40 & Nama Karyawan \\
\hline Alamat & text & - & Alamat karyawan \\
\hline Jenis kelamin & varchar & 1 & Jenis kelamin \\
\hline User_name & varchar & 40 & UN Karyawan \\
\hline Password & varchar & 30 & Kata kunci Karyw \\
\hline ID_Pekerjaan & int & 9 & Id. pekerjaan \\
\hline
\end{tabular}

Tabel 13. 2 NF - Pekerjaan

\begin{tabular}{|l|c|c|l|}
\hline \multicolumn{1}{|c|}{$\begin{array}{c}\text { Field } \\
\text { Name }\end{array}$} & $\begin{array}{c}\text { Data } \\
\text { Type }\end{array}$ & $\begin{array}{c}\text { Ran } \\
\text { ge }\end{array}$ & \multicolumn{1}{|c|}{ Description } \\
\hline ID_Pekerjaan & int & 9 & Id. pekerjaan \\
\hline Pekerjaan & varchar & 30 & Nama pekerjaan \\
\hline Gj_Pokok & varchar & 30 & Gaji Pokok \\
\hline BPJS & int & 30 & Asuransi kesehatn \\
\hline TKel & int & 30 & Tunj.keluarga \\
\hline TTrans & int & 30 & Tunj.transportasi \\
\hline TStruk & int & 30 & Tunj.struktural \\
\hline TJab & int & 30 & Tunj.jabatan \\
\hline
\end{tabular}

Tabel 14. 2 NF - Gaji

\begin{tabular}{|l|c|c|l|}
\hline \multicolumn{1}{|c|}{$\begin{array}{c}\text { Field } \\
\text { Name }\end{array}$} & $\begin{array}{c}\text { Data } \\
\text { Type }\end{array}$ & $\begin{array}{c}\text { Ran } \\
\text { ge }\end{array}$ & \multicolumn{1}{|c|}{ Description } \\
\hline ID_gaji & int & 9 & Id. Gaji \\
\hline Tgl & date & - & Tanggal Gaji \\
\hline NIK & int & 2 & No. Induk Karyw \\
\hline
\end{tabular}

Tabel 15. 2 NF - Perusahaan

\begin{tabular}{|c|c|c|c|}
\hline Field & $\begin{array}{c}\text { Data } \\
\text { Type }\end{array}$ & $\begin{array}{c}\text { Ran } \\
\text { ge }\end{array}$ & Description \\
\hline
\end{tabular}

\begin{tabular}{|l|c|c|l|}
\hline Nm_prusahaan & varchar & 40 & Id. Jabatan \\
\hline Alamat & varchar & 50 & Id. Gaji \\
\hline Logo & varchar & - & Tanggal Gaji \\
\hline Home & varchar & - & No. Induk Karyw \\
\hline Prosedur & varchar & - & Gaji Pokok \\
\hline Admin & varchar & - & Asuransi kesehatn \\
\hline
\end{tabular}

Tabel 16. Derajat Faktor Jabatan

\begin{tabular}{|l|c|c|l|}
\hline \multicolumn{1}{|c|}{$\begin{array}{c}\text { Field } \\
\text { Name }\end{array}$} & $\begin{array}{c}\text { Data } \\
\text { Type }\end{array}$ & $\begin{array}{c}\text { Ran } \\
\text { ge }\end{array}$ & \multicolumn{1}{|c|}{ Description } \\
\hline ID_Jabatan & int & 9 & Id. Jabatan \\
\hline Jabatan & varchar & 30 & Nama jabatan \\
\hline Pendidikan & varchar & 30 & Pendd karyawan \\
\hline Pengalaman & int & 2 & Penglm karyawan \\
\hline Inisiatif & varchar & 30 & Inisiatif karyawan \\
\hline Usaha Fisik & varchar & 30 & U. fisik karyawan \\
\hline Usaha Mental & varchar & 30 & U. mental karywn \\
\hline Peralatan & varchar & 30 & Tggjwb alat kerja \\
\hline Bahan Produk & varchar & 30 & Tggjwb bahan \\
\hline Safety_Orang & varchar & 30 & Tggjwb keamann \\
\hline Job_Orang & varchar & 30 & Tggjwb pekerjaan \\
\hline Kondisi_Job & varchar & 30 & Kondisi pekerjaan \\
\hline Risiko_Job & varchar & 30 & Risiko pekerjaan \\
\hline Tot_Point & int & 25 & Total Point Jabatn \\
\hline
\end{tabular}

Entity Relationship Diagram (ERD) dari Sistem Informasi Penggajian berbasis point system seperti yang ditunjukkan dalam Gambar 2, dimana satu karyawan hanya memiliki satu jabatan berdasarkan derajat faktor jabatan sehingga memiliki hanya satu gaji juga, sementara admin dapat mengolah atau membuat banyak karyawan dan banyak laporan penggajian berdasarkan data karyawan

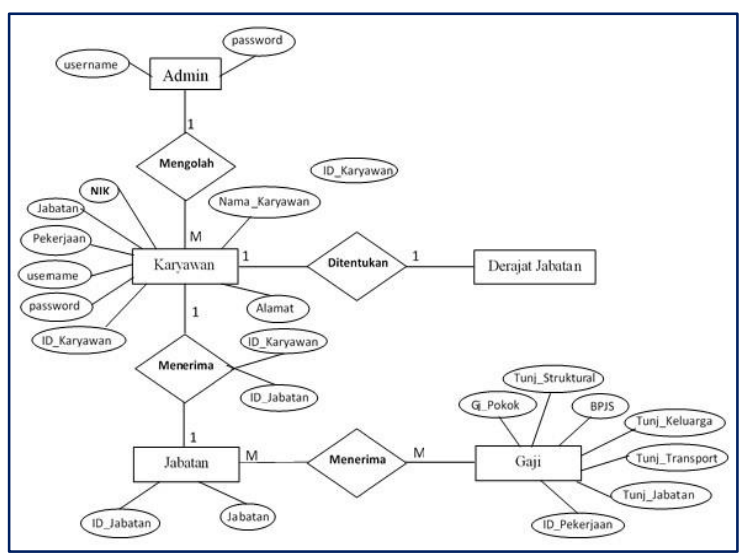

Gambar 2. ERD Sistem Informasi Penggajian

Use case yang dapat digambarksn dalam Sistem Informasi Penggajian ini dapat dilihat pada gambar berikut ini: 


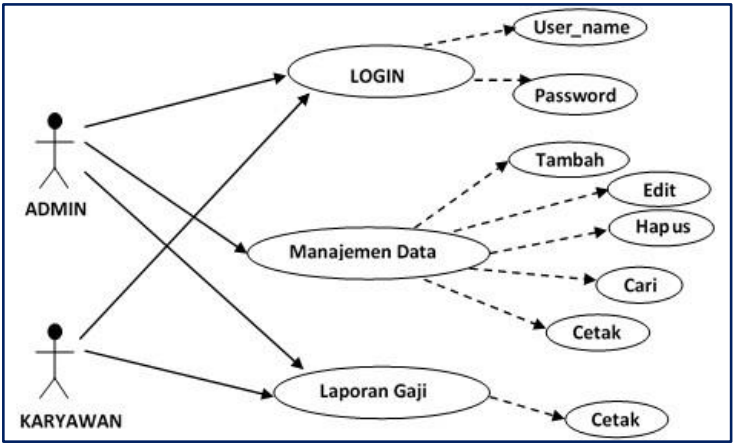

Gambar 3. Use Case Diagram SI. Penggajian

Rancangan untuk tampilan login sebagaimana ditunjukkan dalam gambar berikut ini:

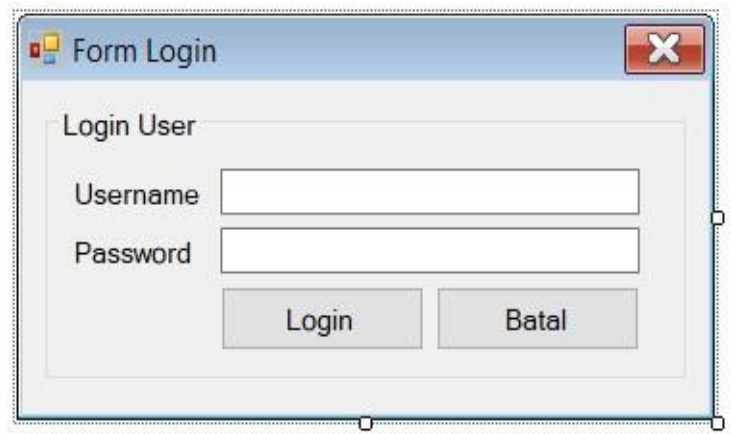

Gambar 4. Tampilan Login User

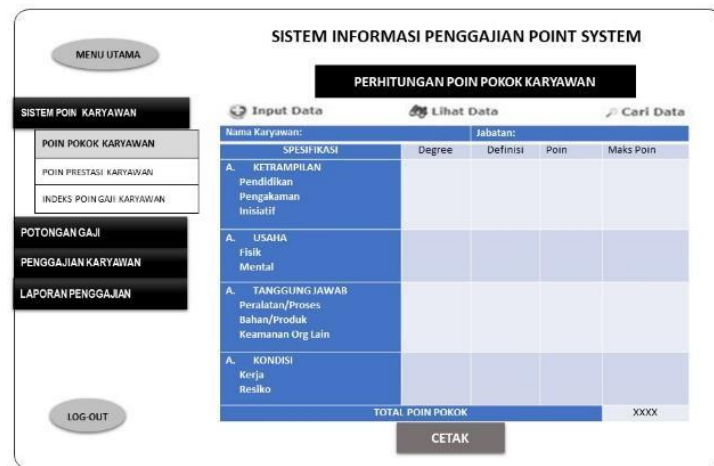

Gambar 5. Tampilan Menu Perhitungan Poin

\section{ALGORITMA ATAU PROGRAM}

Algoritma dari sistem informasi penggajian (Setiawan Dimas, 2020) dapat digambarkan sebagai berikut:

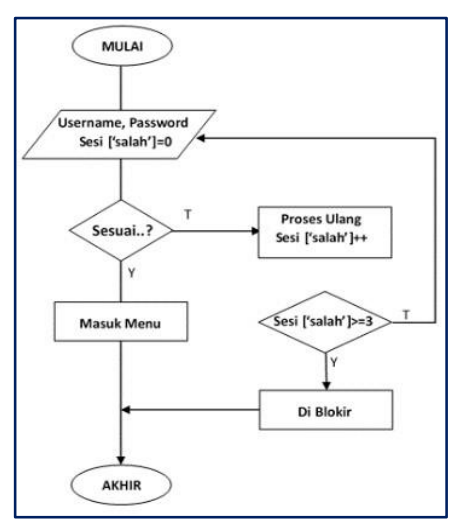

Gambar 6. Flowchart Login

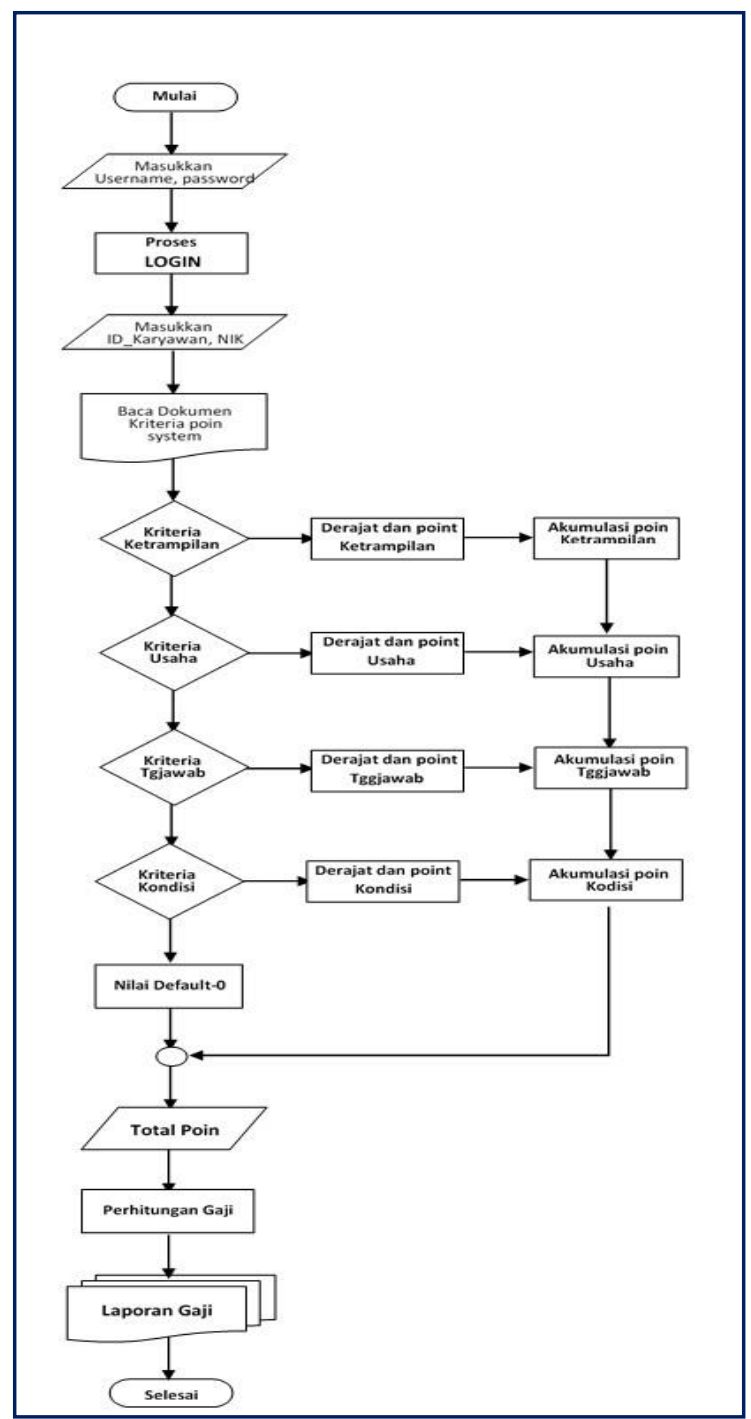

Gambar 7. Flowchart SI. Penggajian 


\section{KESIMPULAN}

Manajemen fungsional yang cukup pelik didalam dunia usaha adalah masalah Sumber Daya Insani (Manusia) terkhususkan pada permasalahan penggajian, yakni masalah kelayakan atau kesesuaian serta masalah pelayanan informasi. Faktor kelayakan atau kesesuaian dalam penggajian merupakan besaran yang proporsional atau dapat diartikan keadilan, sedangkan faktor pelayanan informasi merupakan peningkatan terhadap penyampaian informasi yang tepat waktu (timeliness).

Untuk mengatasi kedua faktor ini, maka dibutuhkan:

a. Sebuah model sistem penggajian yang didukung dengan sistem informasi yang memadai, dan sistem penggajian tersebut adalah dengan menggunakan point system, yaitu model penggajian setiap karyawan berdasarkan evaluasi jabatan atau pekerjaan melalui pengukuran kapasitas dan kapabilitas serta prestasi yang diberikan kepada setiap karyawan,

b. Setiap komponen yang di evaluasi ditetapkan besaran poin sebagai penentuan besaran gaji yang diterima dari hasil perkalian poin terhadap besaran koin (nilai uang) per poin.

c. Untuk mendapatkan kualitas informasi yang profesional pada sistem penggajian dengan point system ini, maka sistem akan dikelola dengan berbasis komputer, sehingga perlu adanya sebuah pemodelan sistem informasi agar sistem tersebut dapat mencapai tujuan yang diharapkan berdasarkan kebutuhan manajemen perusahaan.

d. Hasilnya, setiap karyawan akan mendapatkan besaran gaji yang accountable dan transparence melalui sebuah sistem informasi yang berbasis komputer.

e. Rekomendasi yang dapat diberikan adalah pemrograman (coding) dari sistem penggajian berdasarkan point system ini atau dengan melakukan pengembangan sistem yang berbasis sms gateway atau berbasis android

\section{PUSTAKA}

Hasibuan. (2002). Gaji; Definisi, Peranan, Fungsi dan Tujuan Penggajian. https://jurnalsdm.blogspot.com/2009/05/gaji-definisiperanan-fungsi-dan-tujuan.html

Moenir, A., \& Yuliyanto, F. (2017). Perancangan Sistem Informasi Penggajian Berbasis Web dengan Metode Waterfall pada PT. Sinar Metrindo Perkasa (Simetri). Jurnal Informatika Universitas Pamulang, 2(3), 127137. https://doi.org/10.32493/INFORMATIKA.V2 I3.1237

MUNIARTO. (2017). Rancang Bangun Sistem Informasi Penggajian Karyawan Pada
Koperasi Anging Mammiri Makassar Berbasis Web. Uin Alauddin Makassar.

Poerwono. (n.d.). Makalah Gaji (Definisi, Peranan, Fungsi dan Tujuan Penggajian) - Dunia Makalah. Retrieved September 24, 2021, from https://andyyjr20.blogspot.com/2019/02/maka lah-gaji-definisi-peranan-fungsi.html

Ranupandojo, H., \& Husnan, S. (1994). Manajemen personalia (Ed. 4, cet). Yogyakarta: BPFE. https://opac.perpusnas.go.id/DetailOpac.aspx ?id=146482

Sastra Ricky, N. M. B. S. (2019). Perancangan Sistem Informasi Penggajian Menggunakan Model Waterfall Pada Pt. Medina. Repository Nusamandiri, 71-78. https://repository.nusamandiri.ac.id/index.php /repo/viewitem/15059

Setiawan Dimas. (2020). Contoh Program Java Menghitung Gaji Karyawan, Kelas Programmer. https://kelasprogrammer.com/contohprogram-java-menghitung-gaji-karyawan/

Toban, C., \& Sjahruddin, H. (2016). The Antecedent and Consequence of Organizational Commitment and Job Satisfaction. Journal of Business and Management Sciences, Vol. 4, 2016, Pages 26-33, 4(2), 26-33. https://doi.org/10.12691/JBMS-4-2-1 